\title{
Effectiveness and Limitations of Vegetation Bioshield in Coast for Tsunami Disaster Mitigation
}

\author{
Norio Tanaka \\ Graduate School of Science and Engineering, Saitama University
}

Japan

\section{Introduction}

Tsunamis are one of the most awful natural disasters that can cause catastrophic damage to both human life and socioeconomic property. When a tsunami reaches a coast, it may appear as a rapidly falling or rising tide or a series of breaking waves. When a tsunami reaches the shore, part of the tsunami wave is reflected offshore, but most of it slows down, increases in height, runs up towards the land with huge energy, and causes massive destruction on the coast and in the hinterlands.

Mitigation, preparedness, and escape are representative countermeasures to protect human lives and infrastructure facilities from natural hazards. Mitigation techniques are broadly categorized in two ways. These are artificial methods (hard solutions) and natural methods (soft solutions utilizing a natural buffer zone of coastal vegetation, sand dunes, lagoons, or coral reefs). Artificial methods are mainly kinds of sea walls (huge embankments, tsunami gates) that can be constructed on the coastal area for any predicted tsunami height. However, the construction costs of the artificial methods can be very high, which restricts development in many cases. Some developed countries like Japan, which has frequent tsunamis or storm surge threats, have employed such techniques. On the other hand, the use of coastal vegetation as a natural method for disaster mitigation was also discussed in Japan more than 100 years ago (Honda, 1898).

Recently, natural methods have been widely understood to reduce the tsunami energy remarkably, although they cannot completely stop the tsunami itself, and their effectiveness depends on the magnitude of the tsunami and the type of vegetation structure (Tanaka et al., 2007). Shuto (1987) analyzed the effects and limitations of coastal vegetation from historical records of tsunamis that occurred in Japan. Especially, since the 1998 Papua New Guinea tsunami (Dengler \& Preuss, 2003), many researchers have begun investigating the effects of coastal vegetation on tsunami mitigation using water flume experiments (Harada \& Imamura, 2000), field investigations and numerical simulations (Hiraishi \& Harada, 2003). After the Indian Ocean tsunami on 26 December 2004, further research was conducted to elucidate the effectiveness of coastal vegetation (Danielsen et al., 2005; Kathiresan \& Rajendran, 2005, 2006; Dahdouh-Guebas et al., 2005; Harada \& Imamura, 2006; Tanaka \& Sasaki, 2007; Tanaka et al., 2006a, 2006b, 2007; Sasaki et al., 2007; Nandasena et al., 2007) in 
order to minimize infrastructure damage and protect human lives. Danielsen et al. (2005) pointed out that the deterioration and clearing of mangroves and other types of coastal vegetation along many coastlines has increased their vulnerability to storm and tsunami damage. Many field investigations after the huge tsunami suggest that establishing or strengthening greenbelts of mangroves and other coastal forests may play a key role in reducing the effect of future extreme events. Therefore, natural methods that employ coastal vegetation together with other natural features such as sand dunes or lagoons have been studied because they require relatively little capital investment compared to artificial measures, provide human-friendly beach fronts, and enhance inter-relationships with other ecological systems.

For optimal planning of the natural systems and their maintenance, the effects of vegetation on the reduction of tsunami energy are to be quantitatively elucidated. This requires knowledge of the limitations of coastal forests in tsunami mitigation and consideration of how to maintain the forest as a natural disaster buffer zone. The objectives of this article are to review the important points about the 1) effectiveness and vulnerability of coastal forests against tsunami revealed by field investigations, 2) implications of results obtained from numerical simulations, 3) breaking conditions of coastal tree species and forests, and 4) future establishment and management of coastal vegetation.

\section{Effectiveness and vulnerability of coastal forests against tsunami revealed by field investigations}

\subsection{Effectiveness of coastal forests in tsunami mitigation}

Dengler \& Preuss (2003) investigated the disaster caused by the 1998 Papua New Guinea tsunami and found that Casuarina trees presented relatively greater resistance than palm trees. However, they pointed out the need to conduct further research in understanding the interaction of trees, roots, and high-flow water regimes in order to utilize vegetation as a tsunami abatement measure because significant scouring occurred in the areas where the root systems were undermined, and in some cases, trees caused additional damage to their surroundings in the fast-moving water. This demerit was also pointed out by Shuto (1987).

Kathiresan \& Rajendran (2005) concluded that the presence of mangroves reduced the human death toll along the Tamil Nadu coast of southeast India, although Kerr et al. (2006) argued that all mechanistically important factors should be addressed in considering the issue. However, the buffering behavior of mangroves has been examined in many other post-tsunami investigations. Dahdouh-Guebas et al. (2005) showed by cluster analysis that the man-made structures located directly behind the most extensive mangroves were less damaged, while Danielsen et al. (2005) reported that a dense mangrove of Rhizophora spp. and Avicennia spp. (density $=14-26$ tree trunks per $100 \mathrm{~m}^{2}$ ) contributed to decrease damage in $96 \%$ of surveyed cases in India. Exposed villages suffered the highest levels of damage, and those behind mangroves experienced intermediate levels of damage.

Tanaka et al.(2007) showed some examples that coastal vegetation could reduce the tsunami velocity, and water depth by comparing damage situations with/without vegetation in Sri Lanka and Thailand. Fig.1 (a) shows a schematic of the tsunami damage at Kalutara, Sri Lanka. The Cocos nucifera trees growing along the coast (Line A) were 3-7 $\mathrm{m}$ in height and 3 $\mathrm{m}$ apart, but some of them were damaged, and houses behind the trees were damaged up to 
$100 \mathrm{~m}$ from the coast. Pandanus odoratissimus and Casuarina equisetifolia were found as coastal vegetation at Line B, $500 \mathrm{~m}$ south of Line A and near the mouth of the Kalu Ganga (river). The vegetation width in the tsunami direction was $20 \mathrm{~m}$ and $40 \mathrm{~m}$ for $P$. odoratissimus and $C$. equisetifolia, respectively. At the interface, $P$. odoratissimus and C. equisetifolia were mixed for a distance of about $20 \mathrm{~m}$. The tsunami height $60 \mathrm{~m}$ inland from the coast was $0.6 \mathrm{~m}$, and the houses located within this area were not as damaged because the tsunami height was low compared to its height at Line A. It is supposed that the tsunami current was repelled by the vegetation because they played a role in blocking the current.

Fig.1(b) shows an example how the growth stage affects tsunami inundation. At Line A, the tsunami, about $3 \mathrm{~m}$ high at the coast, swept about $1.8 \mathrm{~km}$ inland. It passed through $200 \mathrm{~m}$ of C. equisetifolia vegetation. The forest does not contribute the tsunami mitigation. The trunk diameter of the trees was about $0.5-1 \mathrm{~m}$, but the forest density is very low. At Line $\mathrm{B}, \mathrm{C}$. equisetifolia is younger and the density is larger in comparison with Line A. The tsunami broke young C. equisetifolia, the trunks of which were about $0.07 \mathrm{~m}$ in diameter. However, the broken trees and branches were accumulated in front of the C. equisetifolia of which trunk diameter is larger than $0.1 \mathrm{~m}$. It had a role to repell the current.

\subsection{Effects of forest density, tree-trunk diameter, and stand structure of trees}

Field surveys in Sri Lanka and Thailand after the Indian Ocean tsunami showed that older (larger diameter) Casuarina equisetifolia belts on the coast withstood the tsunami but failed to provide good protection (Tanaka et al., 2006a, 2006b, 2007). Tanaka et al. (2007) showed that tree growth and forest density can have a significant effect on tsunami mitigation because trees with larger trunk diameters require more space (lower tree density) between them to grow. It suggests that trunk diameter and density effect, important parameters for estimating vegetation drag, cannot be discussed independently. Tanaka et al. (2007) reported that the relationship between the crown height and tsunami height is also important in terms of the drag characteristics of broad-leaved trees because they have branches with large diameters. The United Nations Food and Agriculture Organization (FAO) (2007) pointed out that active forest management is required to produce variouslyaged stands of trees with a range of sizes and with branches at all levels to enhance the potential for mitigation, particularly in smaller tsunamis, because the mitigation potential of Pinus spp. and Casuarina spp. declines with age due to self-thinning (density is decreased) and because tree crown height exceeds the tsunami water depth, etc.

A combination of different tree species is recommended in a buffer forest (Tanaka et al., 2007, 2008b, 2009). Pandanus odoratissimus (Fig.2a) was observed to grow under the shade of the taller Cocos nucifera and Casuarina equisetifolia (Fig.2b). In field observations, two layers of vegetation, $P$. odoratissimus and $C$. equisetifolia, in the vertical direction exhibited a strong potential to decrease the damage behind the vegetation cover (Tanaka et al., 2007), but a combination of $P$. odoratissimus and $C$. nucifera had little effect because they leave wide gaps vertically. C. equisetifolia is recommended as an appropriate tree species for a mixed forest. If it does not break, it traps debris. Considering the other roles, i.e. trapping debris and providing something to climb to escape or a soft-landing place for people, that coastal vegetation plays (Shuto, 1987; Tanaka et al. 2006b, 2007), a two-layer forest of $P$. odoratissimus and dense C. equisetifolia should be planted and preserved near the coast, and other broad-leaved trees should be grown behind this buffer forest (towards inland), as shown in Fig. 3 (Tanaka et al., 2007). 

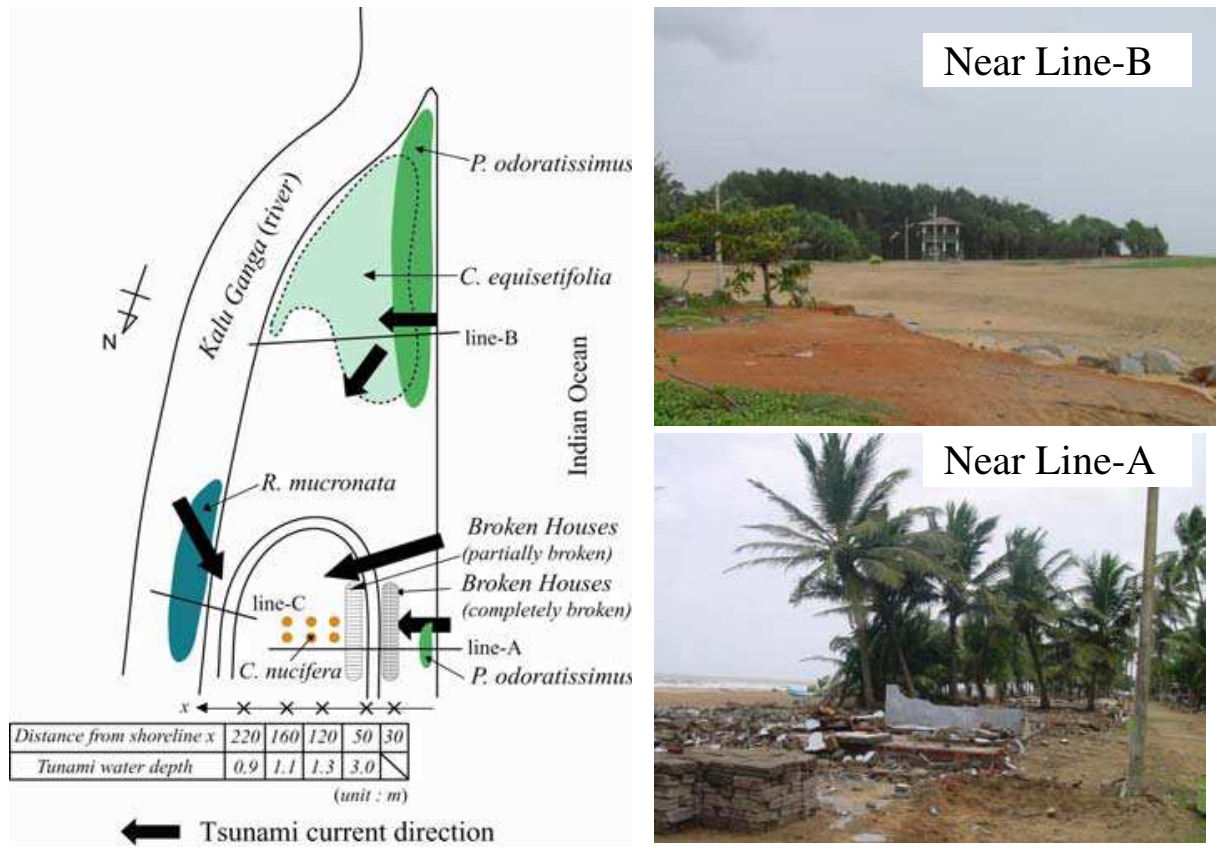

(a)
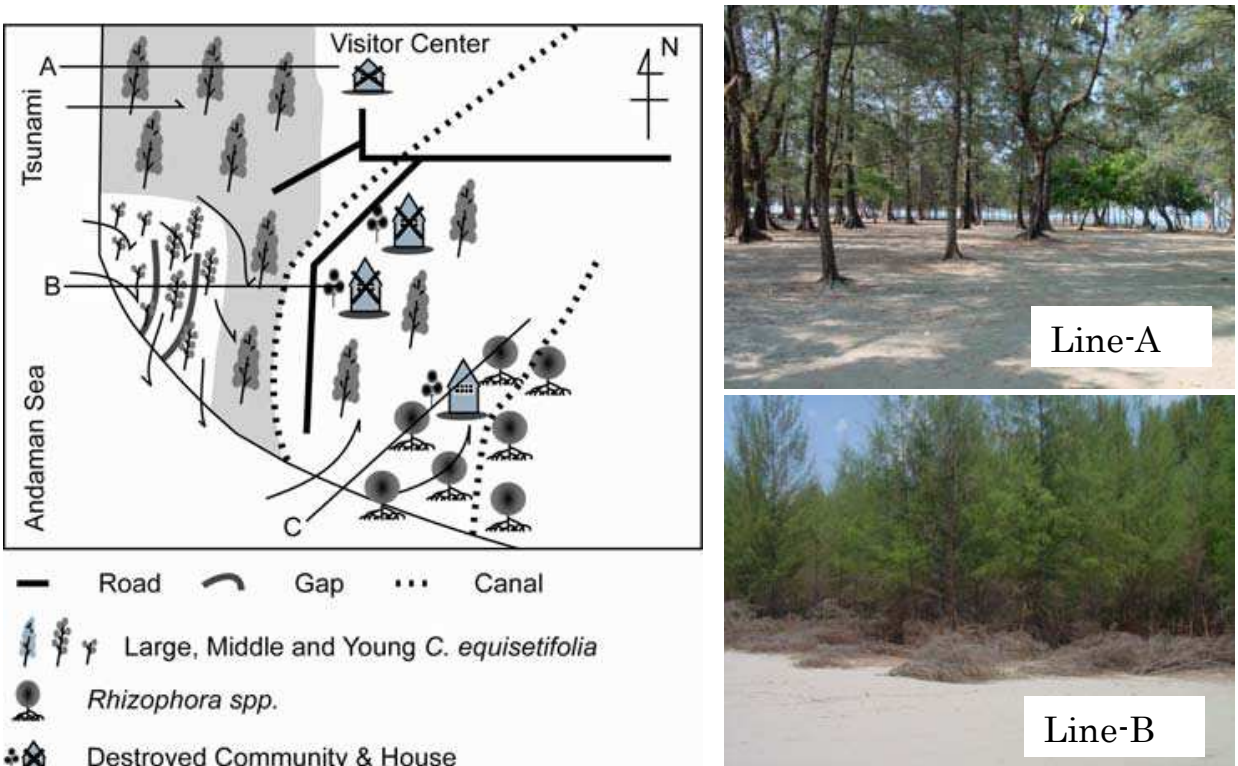

(b)

Fig. 1. Tsunami disaster situation after the 2007 Indian Ocean tsunami, (a) Kalutara, (b) Laem son National Park 


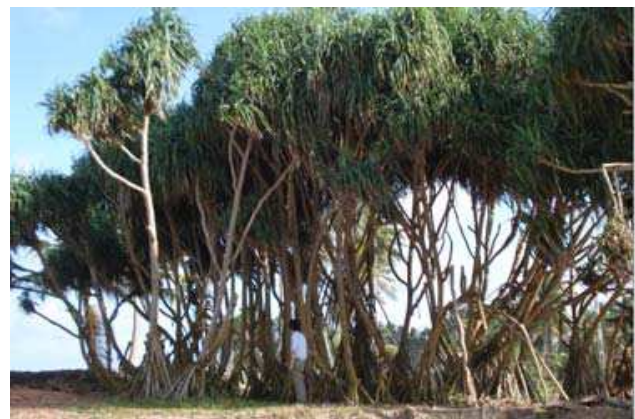

(a)
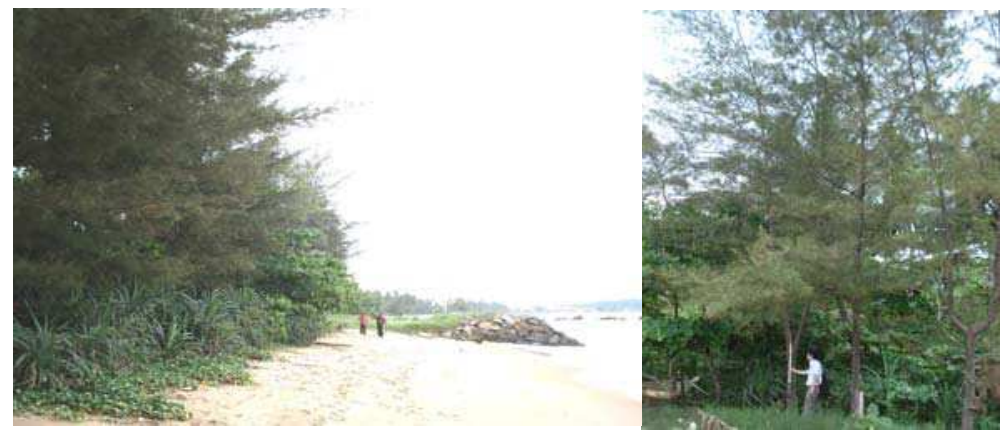

(b)

Fig. 2. Effective coastal vegetation, (a) Pandanus odoratissimus, and (b) Casuarina equisetifolia in tropical countries (undergrowth bushes is young $P$. odoratissimus)
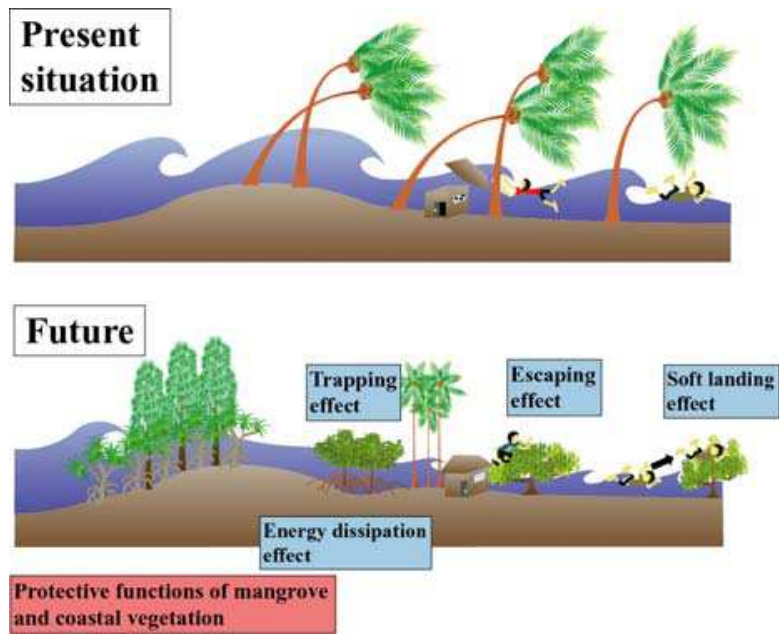

Fig. 3. Functions of coastal vegetation for tsunami disaster mitigation (modified from Tanaka et al.(2007)) 


\section{Implications from numerical simulations}

\subsection{Effectiveness of coastal vegetation for reducing velocity and runup height of tsunamis}

A densely grown coastal vegetation belt of $P$. odoratissimus for reducing the tsunami energy was quantitatively analyzed by an enhanced one-dimensional numerical model that included variations of topography and tsunami characteristics (Nandasena et al., 2008b). The drag and inertia forces were assumed as the total resistance generated by the vegetation. Fig. 4 shows an example of their simulation. It can be observed that the wave reflection was dominant at the vegetation front. Vegetation also reduces the velocity, water depth inside forest, and tsunami front arrival. Expecting this kind of vegetation effect, many researches conducted numerical simulations. The model output by Hiraishi \& Harada (2003) suggested a more than $90 \%$ reduction in maximum tsunami flow pressure by a $100 \mathrm{~m}$-wide forest belt when the tree density is very high (30 tree trunks per $100 \mathrm{~m}^{2}$ ). Model results obtained by Harada \& Imamura (2006), and Tanaka et al. (2006a, 2008b) for various types of coastal vegetation, including mangroves, were very similar. Tanaka et al. (2006a) modelled the relationship of species-specific differences in drag coefficient to tsunami height. The species differences in mitigating tsunami water depth, velocity, and tsunami arrival time behind a forest in relation to tsunami height were found to be quite large, and $P$. odoratissimus was considered more effective in reducing the velocity and water depth of the current through the forest than other common trees, including the coconut tree (C. nucifera) and a kind of mangrove (Avicennia alba) using a numerical simulation (Tanaka et al., 2006a). These results point out the importance of preserving or selecting appropriate species to act as tsunami barriers and offer sufficient shoreline protection. For P. odoratissimus, extensive numerical simulations were conducted and effects of the vegetation has been quantitatively evaluated with many different tsunami conditions by Thuy et al.(2010b)

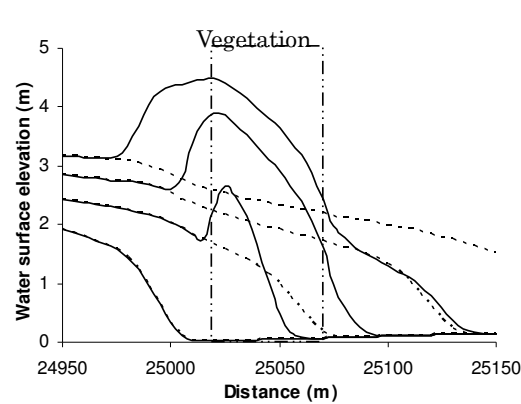

(a)

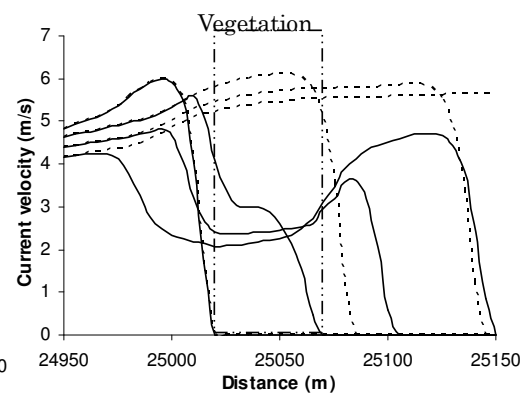

(b)

Fig. 4. Spatial variation of (a) water depth, and (b) current velocity for tsunami periods of 10 min (modified from Nandasena et al.(2008b)). Line: with vegetation, dashed-line: without vegetation. Flow is from left to right

\subsection{Vulnerability of sand dunes, coastal vegetation, and coral reefs: Open gap problem}

A gap in the coastal zone is reported to increase risks and potential damage behind the forest. Gaps in sand dune vegetation are due to natural or artificial causes, such as 
construction of access roads to a beach or for sand mining, the mouths of rivers, mangrove channels opening onto the sea (FAO, 2007), and coral reefs for constructing headlands or embayments (Fernando et al., 2005). The water flow through the gaps is accelerated as it moves into the constriction (FAO, 2007; Fernando et al., 2005, 2008; Mascarenhas \& Jayakumar, 2008; Thuy et al., 2009). When the gap is narrow, it increases the velocity immediately behind the gap, although the water depth will actually decrease in most cases (Nandasena et al., 2008a). The areas behind a coastal forest can still be protected from the tsunami (FAO, 2007; Thuy et al., 2008), but gaps increase the hazards in the gap line (Fernando et al., 2005, 2008; Cochard et al., 2008). As the gap width increases, the flow velocity at the end of the open gap first increases, reaches a maximum, and then decreases (Fig.5), while the run-up height increases monotonously. The maximum velocity in the condition by Thuy et al.(2009) is 1.7 times the maximum velocity without a coastal forest (Fig.6).

Although the danger at the gap has been pointed out, large number of coastal vegetation belt were still constructed with the gap after the Indian Ocean tsunami. Fig.7 shows the planting situation in eastern coast in Sri Lanka. A lot of Casuarina forests are planted there but some forests has supposed to make dangerous zone behind or around the forest although the tsunami damage in most of the area are supposed to be mitigated. As it is not realistic to consider a coastal forest without any gap in the barrier, careful planning is required in the design of an actual coastal forest to incline the gap direction away from the tsunami current direction or to stagger it to reduce the water velocity through the gap (Thuy et al., 2009).

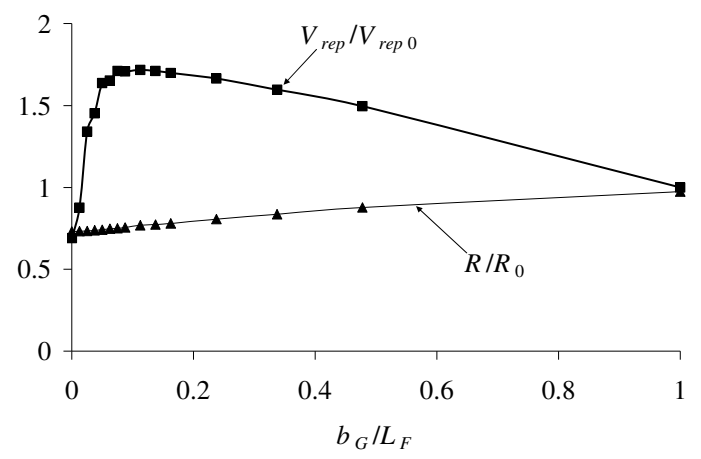

Fig. 5. Variation of representative velocity behind a gap $\left(V_{\text {rep }} / V_{\text {rep } 0}\right)$ and run-up height $\left(R / R_{0}\right)$ in relation to the ratio of a gap width $\left(b_{G}\right)$ and channel width $\left(L_{F}\right)$. Subscript 0 indicates the case of no vegetation. (modified from Thuy et al.(2009))

\section{Breaking conditions of coastal tree species and forest due to tsunami force}

\subsection{Damage to single tree}

Tanaka et al.(2007) reported the damage situation of tress in detail (Fig.8) Main trunks larger than $0.1 \mathrm{~m}$ in diameter were seldom broken by 5-10 m tsunami, except for Rhizophora apiculata (Kang Island in Thailand), which was broken by $8 \mathrm{~m}$ tsunami, Rhizophora mucronata (Medilla in Sri Lanka), by $6 \mathrm{~m}$ tsunami, C. equisetifolia (Ban Thale Nok in Thailand) by $10 \mathrm{~m}$ tsunami, and P. odoratissimus (Hikkaduwa, Medilla in Sri Lanka) by 5-6 $\mathrm{m}$ tsunami. The 


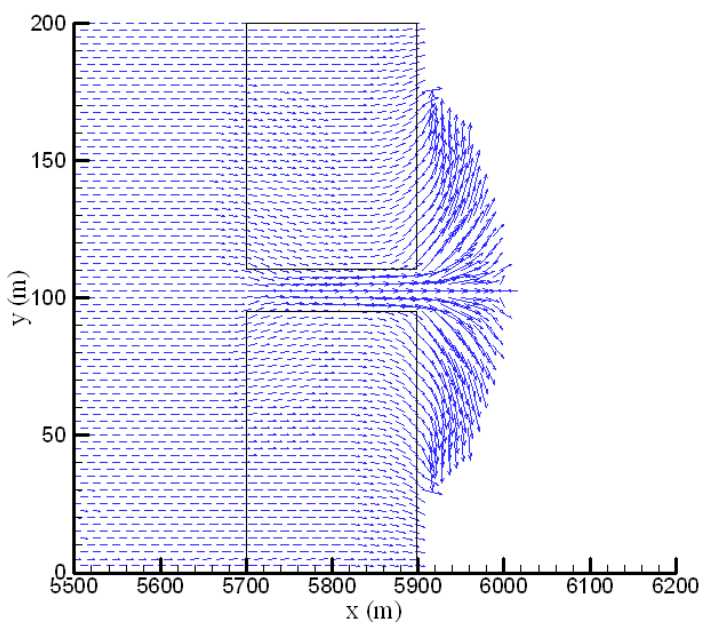

Fig. 6. Flow pattern around a gap (modified from Thuy et al.(2009))
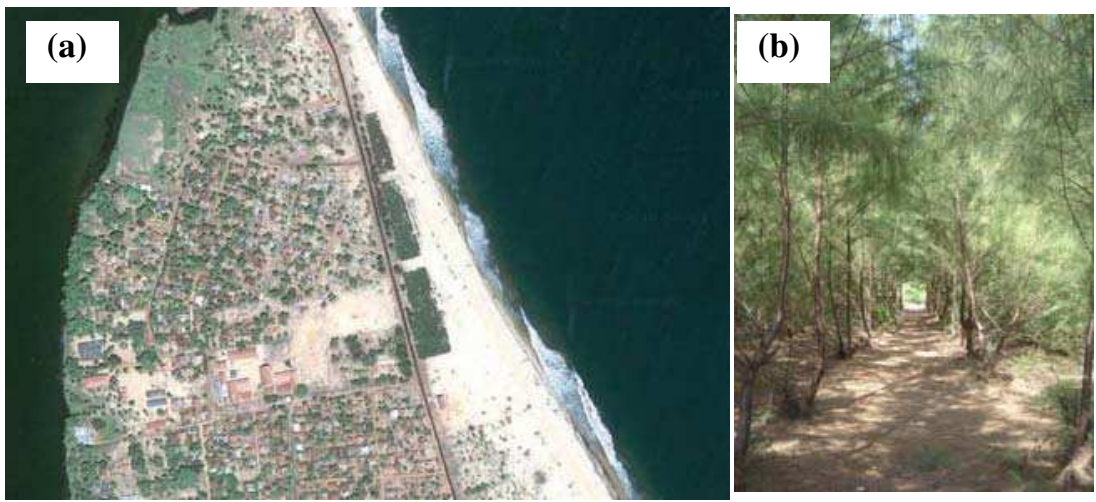

Fig. 7. Planting situation in eastern coast in Sri Lanka, (a) aerial photo (from Google Earth), (b) straight gap inside forest (photo by Methsiri Samarakoon)

pattern of uprooting was related to the strength of the substrate and was usually observed at the front line of the vegetation (Fig. 8(a), (c)). P. odoratissimus and R. apiculata-type trees have many aerial roots, and the moment by drag force can be shared by the aerial roots. Thus, they were able to withstand a less than $5 \mathrm{~m}$ tsunami, even with debris attached to the aerial roots and additional force applied. However, if the drag moment exceeded the threshold for the breaking moment when the tsunami water was high, the trunks were broken just above the aerial roots (Fig. 8(b),(d)).

Tanaka et al. (2006b, 2008b) conducted tree breaking tests in situ using small diameter trunks or branches and showed that the breaking moment curve of representative tree species (Fig.9) can be classified into three parts by elasticity and habitat as

1. the curve for coastal vegetation (ex. P. odoratissimus),

2. the curve for elastic trees

3. the curve for trees with hard trunks (ex. C. equisetifolia). 


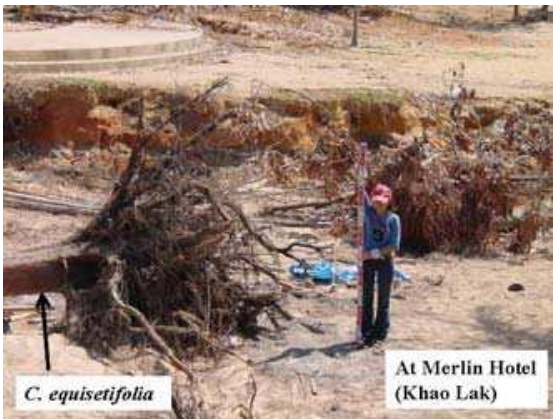

(a)

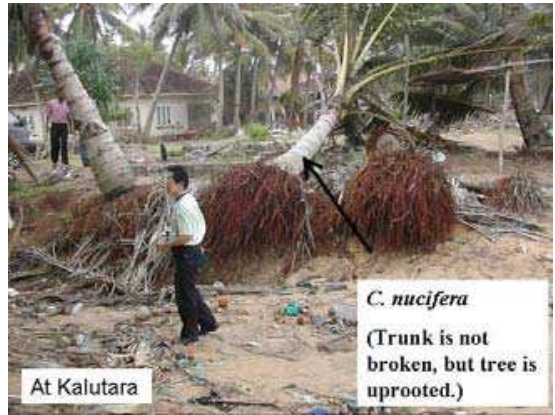

(c)
Broken P. odoratissimus

at Medilla

(b)

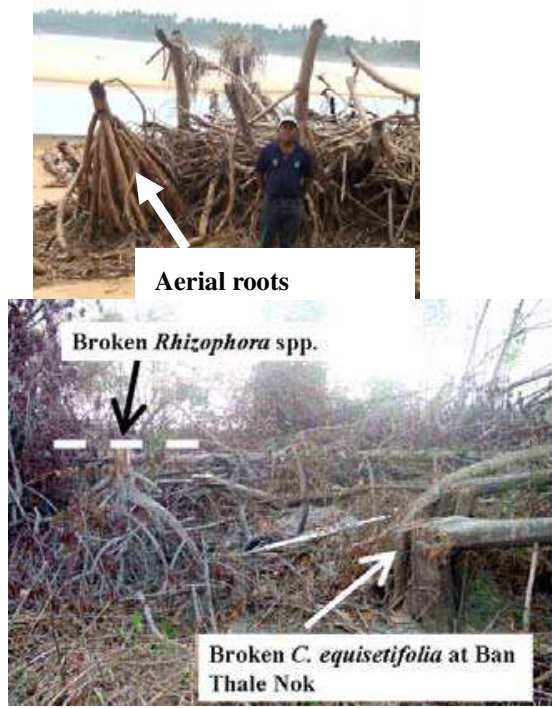

(d)

Fig. 8. Damaged tree patterns, (a) erosion and overturning of Casuarina equisetifolia, (b) tree trunk breakage of Pandanus odoratissimus, (c) uprooted Cocos nucifera, (d) tree trunk breakage of C. equisetifolia and Rhizophora spp.

Although the breaking test was conducted in Sri Lanka before the 2006 Java tsunami (Tanaka \& Sasaki, 2007), the breaking condition coincided well with the actual damage observed at the sites of the Java tsunami, except for C. equisetifolia (Tanaka et al., 2009). C. equisetifolia does not have aerial roots, but its diameter becomes greater at ground level than at breast height as the tree grows. Thus, its trunk was rarely broken. Most of the damage to C. equisetifolia was due to uprooting. This indicates that the breaking condition is not well expressed by the breaking test using $C$. equisetifolia with small trunk diameters. Further study of the breaking or uprooting conditions for C. equisetifolia is recommended with realscale breaking or uprooting tests like those of Peltola et al. (2000) because C. equisetifolia is expected to be an effective species for dissipating tsunami energy in Sri Lanka, Thailand (Tanaka et al., 2006a, 2006b, 2007; FAO, 2007), and India (Mascarenhas \& Jayakumar, 2008).

Tanaka \& Sasaki (2007) examined the height at which P. odoratissimus and C. nucifera trees were broken in two tsunamis (the 2004 Indian Ocean and 2006 Java tsunamis) and found that the threshold of tsunami water depth at which a tree trunk broke was about $80 \%$ of the tree height for P. odoratissimus (Fig.10). C. nucifera was seldom damaged except for small trees, but when it was toppled, the critical tsunami height was about $80 \%$, the same as $P$. odoratissimus. Because the breaking point of $P$. odoratissimus is $1-2 \mathrm{~m}$ high, the moment by drag at that point is smaller than that of a tree without aerial roots. Although the threshold tsunami water depth for breaking P. odoratissimus is similar to that for C. nucifera, the trunk 
strength of $P$. odoratissimus is not as great and it receives a large drag force from the tsunami current when the tsunami water depth is greater than the height of its aerial roots.

The studies by Tanaka \& Sasaki (2007) and Tanaka et al. (2008b) elucidated the breaking condition for a single tree when the scouring around the tree is not severe. However, the breaking condition is not applicable for critical tree damage in the fringe area of a forest, especially the frontal vegetation on sand dunes where the substrate is not hard and severe scouring occurs.

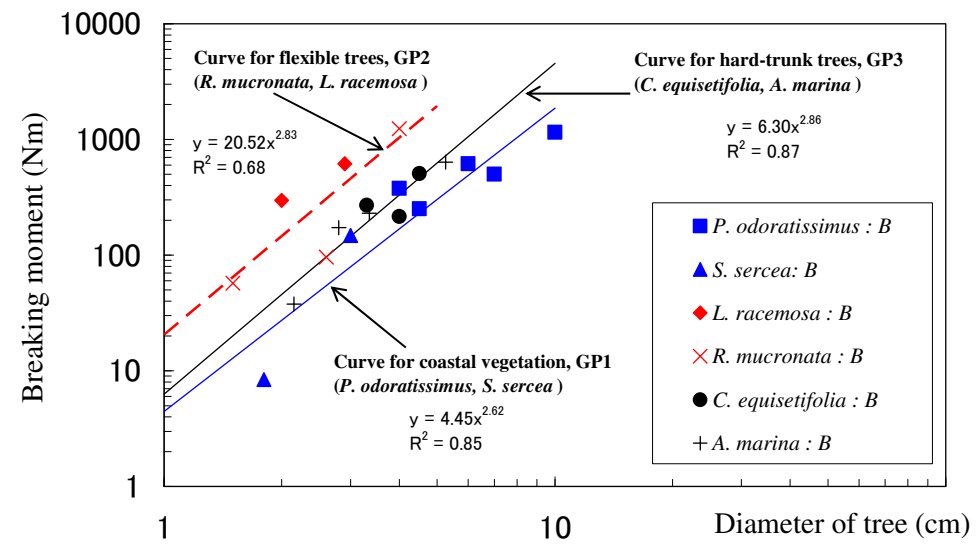

Fig. 9. Breaking moment curve of representative coastal tree species in tropics (modified from Tanaka et al.(2009))

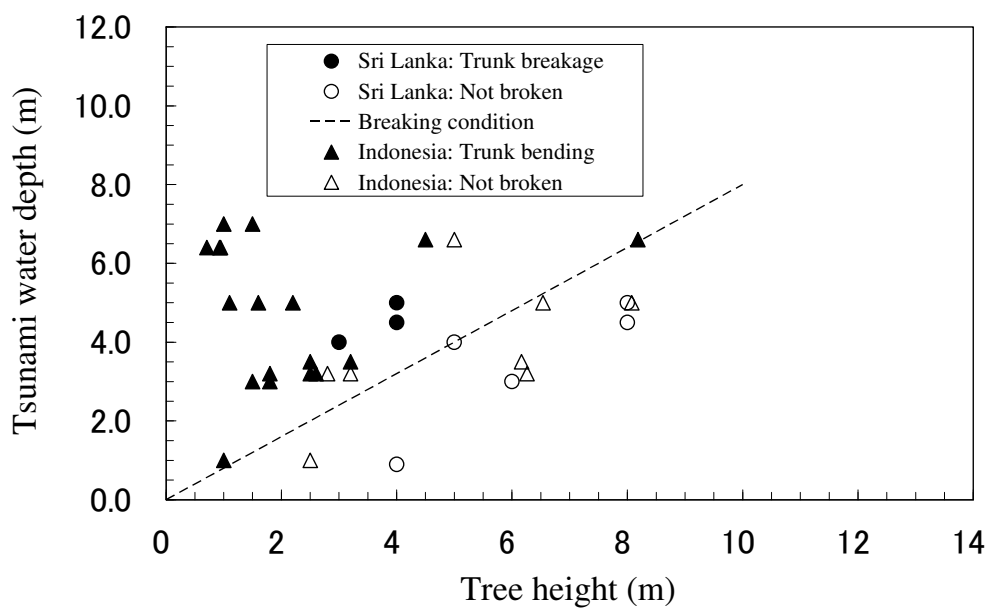

Fig. 10. Tree breaking situation in relation to tsunami water depth and tree height (modified from Tanaka \& Sasaki (2007) 


\subsection{Parameters of effects and limitation of coastal forest for tsunami mitigation}

Shuto (1987) discussed the effectiveness and limitations of a forest on the reduction of tsunami energy. He classified the degrees of damage to a forest due to tsunamis, i.e., no damage, tilting or turnover due to large scouring, and trunk breakage or uprooting. The classification was based on the characteristics of a forest from the records of five previous huge tsunamis (in 1896, 1933, 1944, 1960, and 1983) that had occurred in Japan and the forest damage at the tsunami events. The relationships between the tsunami inundation depth and tree diameter at breast height and the extent of the forest were statistically analyzed considering the physical aspects of tsunamis. The length of a forest in the streamwise direction, the size and density of the trees, and the undergrowth are important parameters of tsunami energy reduction. In particular, he derived a simple but important parameter for discussing the degree of the forest damage, the ' $d n^{\prime}$, where $d$ is the tree trunk diameter at breast height $(\mathrm{cm}), n$ is the number of trees in a forest in the streamwise direction and in unit widths in the cross-stream direction (trees within the area of the forest length in the streamwise direction $(\mathrm{m})$ $\times 1 \mathrm{~m}$ in the cross-stream direction) as a major measure of resistance by a forest, assuming that the drag coefficient is constant with the changing tree density.

After the Indian Ocean tsunami, Tanaka et al. (2007) investigated the effectiveness of Shuto's classification (1987). The damage to C. equisetifolia almost satisfied the criteria using the $d n$. However, the $d n$ of Anacardium occidentale and Avicennia alba, broad-leaved trees, and $P$. odoratissimus and Rhizophora apiculata, which have aerial roots, were not well classified because the large diameter branches or aerial roots add additional drag that Shuto (1987) did not consider. Thus, to distinguish the effects of tree species, Tanaka et al. (2007) recommended calculating the effective cumulative tree diameter in the stream-wise direction, $d N_{\text {all }}\left(\mathrm{cm} /\left(\right.\right.$ vegetation width in streamwise direction $\left.\left.(\mathrm{m}){ }^{*} 1 \mathrm{~m}\right)\right)$, as:

$$
d N_{\text {all }}=d n \times \frac{1}{h} \int_{0}^{h} \alpha(z) \cdot \beta(z) d z=d n \times \alpha \beta
$$

Where, $h$ is the tsunami water depth, $\alpha(\mathrm{z}), \beta(\mathrm{z})$ are additional coefficients that expresses the effect of cumulative width of a tree in each height on the drag, and the effect of leaves or aerial roots on the drag, respectively, $\alpha \beta$ is about 1.3, 2, 3 and 3.5 for C. equisetifolia, A. occidentale, $R$. apiculata and P. odoratissimus, respectively for 3-5 $\mathrm{m}$ tsunami.

Mascarenhas \& Jayakumar (2008) also reported the length of vegetation damage in the streamwise direction. Casuarina plantations remained intact except for the frontal strips, a few trees that faced the ocean, when tsunami run-up levels ranged from 0.7-6.5 $\mathrm{m}$ and the length of flooding area from the coast varied from 31-862 m. Although the threshold breaking condition of a single tree has been elucidated (Tanaka \& Sasaki, 2007; Tanaka et al., $2008 \mathrm{~b}$ ) and some investigations reported the breaking length of a forest in the tsunami current direction (Tanaka et al., 2007; Mascarenhas \& Jayakumar, 2008), the breaking length of a forest has still not been quantitatively evaluated according to the tsunami condition. More study is needed to estimate the length because the breaking affects the dissipation of tsunami energy.

\subsection{Limitations of forest}

The tsunami force is directly related to the damage of trees, however, the effects of breaking on numerical simulation results were not directly discussed in previous studies except for Thuy et al.(2010a). Thuy et al.(2010a) developed the numerical model for estimating tsunami bending moment on a tree and including tree breakage, and then the damage length of 
vegetation, reduction of water depth and tsunami force behind the forest are discussed. The study elucidated that: (1) tsunami moment is decreased from the front to the behind due to the decrease in water depth inside the vegetation, and (2) the reduction rate in water depth and tsunami force increases when the incident tsunami water depth exceeds the initial breaking. Fig. 11(a) shows spatial distribution of the maximum tsunami moments $\left(M_{P \max }\right)$ along the forest for two models. According to the result, the damage length of forest by the model including tree breakage (B.M.) is about $77.5 \mathrm{~m}(77.5 \%)$ and increased in comparison with the model that does not include tree breaking (N.B.M.) due to the decrease in vegetation resistance in the front area where vegetation is broken. Fig. 11(b) shows the relationship between the tsunami water depth in front of vegetation in the case of no forest and the reduction of water depth $\left(\left(d_{\max 0}-d_{\max }\right) / d_{\max 0}\right)$, tsunami force $\left(\left(F_{*_{\max 0}}-F_{*_{\max }}\right) / F_{*_{\max 0}}\right)$ behind the forest and survival rate of $P$. odoratissimus (number of remained trees/total tree), where subscript 0 indicates the case of no forest. The results show that trees start breaking at water depth of $4.8 \mathrm{~m}$ (Fig. 11(b), I.B.). When tsunami water depth reaches to $5.5 \mathrm{~m}$ all the trees are broken. The reduction rate in water depth and tsunami force decrease when the tsunami water depth exceeds the initial breaking of water depth.

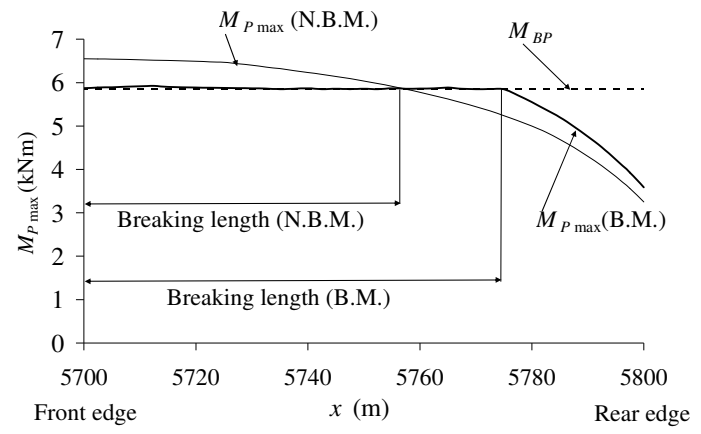

(a)

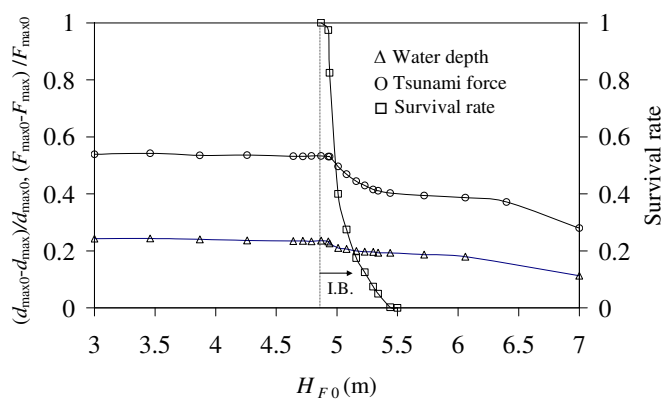

(b)

Fig. 11. (a) Damage length for two numerical model, (b) relationship between tsunami water depth (at the front of vegetation) and reduction of water depth $\left(\left[d_{\max 0}-d_{\max }\right] / d_{\max 0}\right)$, tsunami force $\left(\left[F^{*}{ }_{\max 0}-F^{*}{ }_{\max }\right] / F^{*}{ }_{\max 0}\right)$ and survival rate (number of remained trees / total tree) of $P$. odoratissimus. Subscript 0 indicates the case of no vegetation,(modified from Thuy et al.(2010a)) 


\section{Important aspects of establishment and management of coastal vegetation}

\subsection{Importance of maintenance as observed in Matara pilot project}

A survey was conducted by a team comprising researchers from Saitama University, Japan, and the University of Peradeniya, Sri Lanka (the SU-UoP team) to examine the present situation of coastal vegetation for tsunami mitigation in Sri Lanka. Many government institutions and NGOs have also undertaken such projects along the southern and western coasts in Sri Lanka. An evaluation was carried out to assess whether the coastal vegetation fulfilled the functions of dissipation of wave energy and trapping debris, and offering opportunities to escape and make a soft landing (Tanaka et al., 2007). Currently, $50 \%$ of the vegetation barriers are planted in one or two rows due to land availability constraints in areas along main roads or railway tracks. Dissemination of knowledge and coordination with government institutions and research institutions are very important for establishment and management of effective coastal vegetation for tsunami mitigation with community participation, especially at the initial development stage.

The findings of Tanaka et al. (2007) suggested several options for coastal vegetation management that could effectively reduce the impact of tsunamis and other natural disasters in the future. Accordingly, the SU-UoP team proposed a pilot-scale coastal plantation in the Matara Thotamuna area in the southern coastal belt near the mouth of the Nilwala River, Matara City, Sri Lanka (Fig.12(a)), which was severely affected by the 2004 tsunami. C. equisetifolia and P. odoratissimus were planted in a mixed culture, and their growth was monitored continuously. The average height and girth of $P$. odoratissimus were around 92 $\mathrm{cm}$ and $117 \mathrm{~cm}$, respectively, and the average height and trunk diameter of $C$. equisetifolia were $627 \mathrm{~cm}$ and $4 \mathrm{~cm}$, respectively, 18 months after planting (Perera et al., 2008). The project was very successful and effective compared to similar projects that suffered from poor maintenance and operation. The project indicated that support from local authorities and communities are vital to make such programs successful, especially in initial development stage. For long-term maintenance of the pilot project, management of the site was handed over to the local temple (Fig.12(b)). This is one of the ideas for sustainable maintenance.

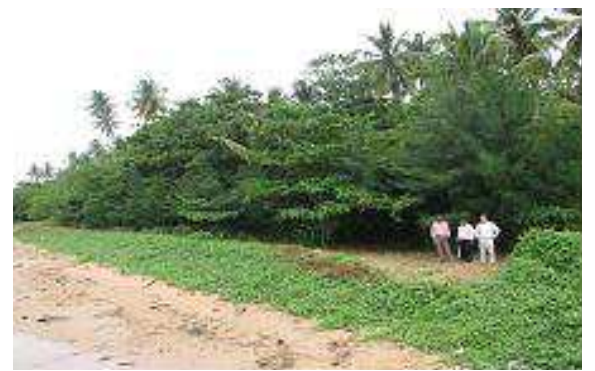

(a)

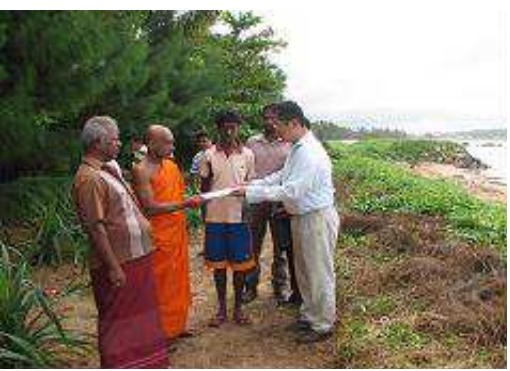

(b)

Fig. 12. Pilot project in Matara city. (a) growth situation after 18 months, (b) long term maintenance by local temple

\subsection{Sustainable maintenance and utilization}

De Zoysa (2008) assessed the impact of a Casuarina shelterbelt from economic (agricultural crop, fuel supply, timber production, household goods), social (attraction of tourists, 
prevention of illegal settlements, prevalence of anti-social activity), and environmental (wind speed reduction, sand dune formation, aesthetic value) viewpoints, and concluded that the environmental and social impacts are larger than the economic impacts. Integrated coastal zone management by the residents, city council, and tourist board is recommended in order to increase the benefits of coastal shelter belts.

Considering the Matara project by the SU-UoP team and the research by De Zoysa (2008), the author recommends an integrated coastal vegetation management system (Fig. 13) that maintains the vegetation bioshield effect for a long time. With the growth of trees, the tsunami energy mitigation effect of the vegetation may be reduced, because the tree spacing becomes larger and effective cumulative tree diameter in the stream-wise direction $d N_{\text {all }}$ is reduced (Tanaka et al., 2007), and the trees themselves limit the light needed for the undergrowth that prevents soil erosion. To keep the forest dense, proper management is needed by using the forest as a source of firewood or for timber production to thin it, and maintaining various-aged stands of trees by replanting (FAO, 2007). In particular, the front line of the forest close to the sea should be dense vegetation (i.e., a Pandanus-Casuarina belt) as Tanaka et al. (2007) proposed. Although C. nucifera cannot provide a large drag on the tsunami current, this species is important for economic use. C. nucifera has many uses, i.e. fruit production, fuel, timber, and coconut fiber is used as water storage and water purification materials in the substrate of manmade wetlands (Tanaka et al., 2008a). Thus, it is not necessary to remove $C$. nucifera from the coastal region if it is kept at the backside of coastal sand dunes or combined with dense Pandanus forest, even though the contribution of C. nucifera to increase the overall drag coefficient by itself is not large.

Mangroves in lagoons are quite important and should be maintained for tsunami mitigation because they reduce the tsunami energy overtopping a sand dune or intruding into the land by a river mouth (open gap). In residential areas, broad-leaved trees that have large diameter branches should be maintained close to the houses for people to escape by climbing during a natural disaster event.

Dense coastal belts are sometimes disliked by residents because illegal settlement or antisocial activities are occurred in the place. For keeping the bioshield, it is also quite important to teach people that the coastal vegetation plays a role in preventing strong winds, salt spray, windblown sand, and storm surge propagation, as well as in mitigating tsunami inundation. The local temple or local authorities can utilize the vegetated area for education of the local residents, teaching them to keep the forest dense, control weeds, especially in the developing stage after plantation, and not to cut the forest illegally.

\section{Conclusion}

Coastal vegetation has been widely recognized as a natural method to reduce the destructive force of tsunami waves, even though the vegetation barrier cannot completely stop a tsunami, and its effectiveness depends on the magnitude of the tsunami as well as the structure of the vegetation. For coastal rehabilitation, optimal planning of natural coastal systems and their maintenance, the capacity of vegetation to reduce the energy of tsunami waves needs to be quantitatively elucidated. The limitations of coastal forests in relation to the magnitude of a tsunami and the maintenance of forests as natural disaster buffer zones have to be understood correctly for effective coastal vegetation planning. Demerits of coastal forests have also been revealed: for example, an open gap in a forest (i.e., a road, river, difference in elevation, etc.) can channel and amplify a strong current by forcing it into the 


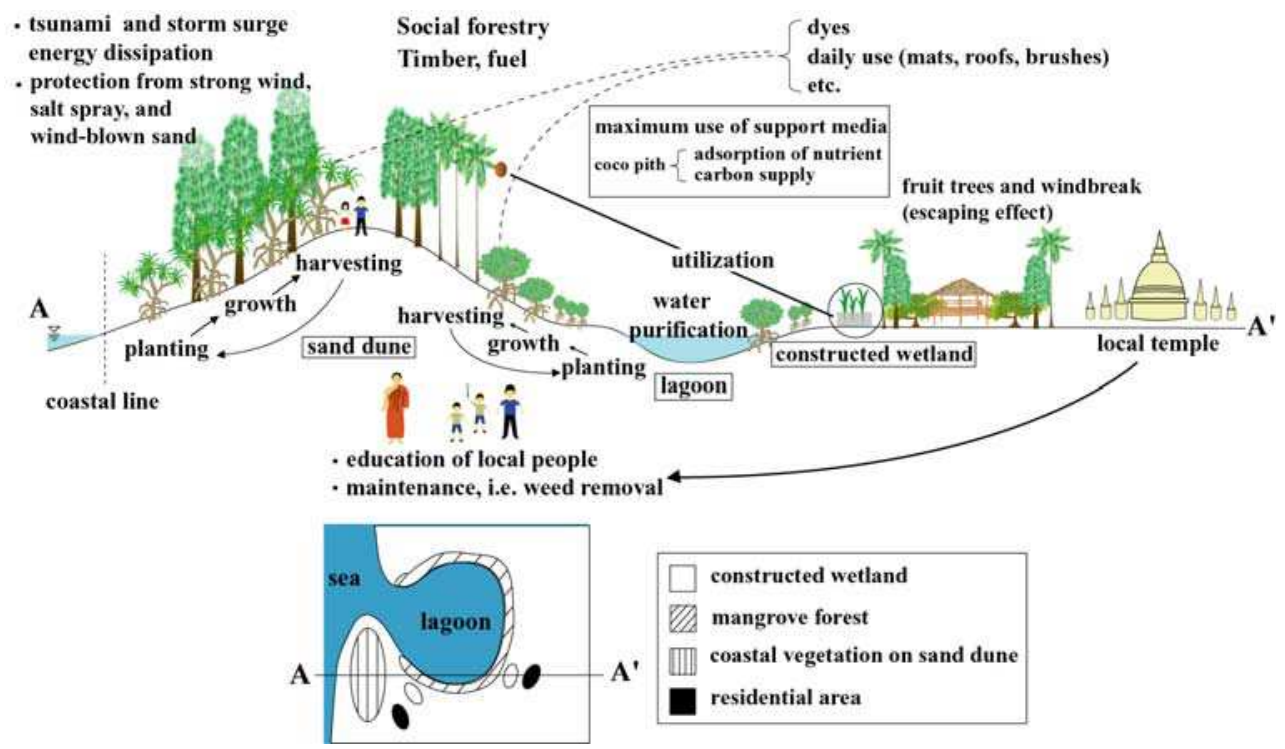

Fig. 13. Integrated coastal vegetation management system (modified from Tanaka et al., 2009)

gap. Floating debris from broken trees also can damage surrounding buildings and hurt people. However, many studies have revealed that these demerits can be overcome with proper planning and management of mangroves and coastal forests, and that coastal vegetation has a significant potential to mitigate damage in constructed areas and save human lives by acting as buffer zones during extreme natural events. The effectiveness of vegetation also changes with the age and structure of the forest (vegetation density, vertical structure and forest shape). This highlights the fact that proper planning and management of vegetation are required to maintain the tsunami buffering function of coastal forests. Although many government and non-government organizations have implemented coastal vegetation projects, many of them have been unsuccessful due to a lack of proper design and maintenance. Many planting project after the Indian Ocean tsunami have dangerous gaps in the coastal forest. A pilot project in Matara City, Sri Lanka, revealed that participation and support from local authorities and communities is essential to make the planting projects successful. An integrated coastal vegetation management system that includes utilization of the materials produced by the forest and a community participation and awareness program are proposed to achieve a sustainable vegetation bioshield.

\section{Acknowledgement}

Prof. Sasaki, Saitama University, Dr. Mowjood and Dr. Jinadasa, University of Peradeniya, are acknowledged for their useful suggestions during field investigations in Sri Lanka. The author would like to thank Mr. Harsha, Mr. Perera, Mr. Fasley and Mr. Methsiri for their help in field measurements, and Prof. Tanimoto, Mr. Thuy and Mr. Nandasena for their help in numerical studies. This review work is partially funded by the JSPS AA Science Platform Program. 


\section{References}

Cochard, R.; Ranamukhaarachchi, S.L.; Shivakoti, G.P.; Shipin, O.V.; Edwards, P.J. \& Seeland, K.T. (2008). The 2004 tsunami in Aceh and Southern Thailand: A review on coastal ecosystems, wave hazards and vulnerability, Perspectives in Plant Ecology, Evolution and Systematics, Vol.10, 3-40.

Dahdouh-Guebas, F.; Jayatissa, L.P.; Di Nitto, D.; Bosire, J.O.; Lo Seen, D. \& Koedam, N. (2005). How effective were mangroves as a defence against the recent tsunami? Current Biology, Vol.15, No.12, 443-447.

Danielsen, F.; Sorensen, M.K.; Olwig, M.F.; Selvam V.; Parish F.; Burgess N.D.; Hiraishi T.; Karunagaran V.M.; Rasmussen M.S.; Hansen L.B.; Quarto A. \& Suryadiputra N. (2005). The Asian tsunami: A protective role for coastal vegetation, Science, Vol.320 , No.5748, 643.

Dengler, L. \& Preuss, J. (2003). Mitigation lessons from the July 17, 1998 Papua New Guinea tsunami, Pure and Applied Geophysics, Vol.160, 2001-2031.

De Zoysa, M. (2008). Casuarina coastal forest shelterbelts in Hambantota City, Sri Lanka: assessment of impacts, Small-scale Forestry, Vol.7, 17-27.

Fernando, H.J.S.; McCulley, J.L.; Mendis, S.J. \& Perera, K. (2005). Coral poaching worsens tsunami destruction in Sri Lanka, Eos, Vol.86, No.33, 301-304.

Fernando, H.J.S.; Samarawickrama, S.P.; Balasubramanian, S.; Hettiarachchi, S.S.L. \& Voropayev, S. (2008). Effects of porous barriers such as coral reefs on coastal wave propagation, J. Hydro-environment Research, Vol.1, 187-194.

Food and Agriculture Organization of the United Nations (FAO) (2007). The Role of Coastal Forests in the Mitigation of Tsunami Impacts - Main report" www.fao.org / forestry / site / coastalprotection / en. ISBN 978-974-13-9321-3, Thammada Press.

Harada, K. \& Imamura, F. (2000). Experimental study on the resistance by mangrove under the unsteady flow, Proceedings of the 1st Congress of the Asian and Pacific Coastal Engineering, pp.975-984, Dalian, China.

Harada, K. \& Imamura, F. (2006). Effects of coastal forest on tsunami hazard mitigation -a preliminary investigation, tsunamis: case studies and recent developments, Advances in Natural and Technological Hazards Research, 279-292.

Hiraishi, T. \& Harada, K. (2003). Greenbelt tsunami prevention in South-Pacific region, Report of the Port and Airport Research Institute, Vol.42, No.2, 23p.

Honda, S. (1898). Über den Küstenshutzward gegen Springfluten. Bulletin of the College of Agriculture 3(4), Imperial University, Komaba, Tokyo, pp.281-298.

Kathiresan, K. \& Rajendran, N. (2005). Coastal mangrove forests mitigated tsunami, Estuarine, Coastal and Shelf Science, Vol.65, No.3, 601-606.

Kathiresan, K. \& Rajendran, N. (2006). Reply to 'Comments of Kerr et al. on "Coastal mangrove forests mitigated tsunami"” [Estuar. Coast. Shelf Sci. 65 (2005) 601-606], Estuarine, Coastal and Shelf Science, Vol.67, 542.

Kerr, A.M.; Baird, A.H. \& Campbell, S.J. (2006). Comments on "Coastal mangrove forests mitigated tsunami" by K. Kathiresan and N. Rajendran [Estuar. Coast. Shelf Sci. 65 (2005) 601-606], Estuarine, Coastal and Shelf Science, Vol.67, 539-541.

Mascarenhas, A. \& Jayakumar, S. (2008). An environmental perspective of the post-tsunami scenario along the coast of Tamil Nadu, India: Role of sand dunes and forests, J. Environmental Management, Vol.89, 24-34. 
Nandasena, N.A.K.; Tanaka, N. \& Takagi, T. (2007). A new derivation of horizontal two dimensional depth averaged momentum equation and continuity equation which include total effect of porosity inside the vegetation, Annual J. Hydraulic Engineering JSCE, Vol.51, 163-168.

Nandasena, N.A.K.; Tanaka, N. \& Tanimoto, K. (2008a). Perspective of coastal vegetation patches with topography variations for tsunami protection in 2D - numerical modeling, Annual J. Hydraulic Engineering JSCE, Vol.52, 133-138.

Nandasena, N.A.K.; Tanaka, N. \& Tanimoto, K.(2008b). Tsunami current inundation of ground with coastal vegetation effects; an initial step towards a natural solution for tsunami amelioration, J. Earthquake and Tsunami, Vol. 2, No.2, 157-171.

Peltola, H.; Kellomäki, S.; Hassinen, A. \& Granander, M. (2000). Mechanical stability of Scots pine, Norway spruce and birch: an analysis of tree-pulling experiments in Finland, Forest Ecology and Management, Vol.135, 143-153.

Perera, W.A.R.P.; Mowjood, M.I.M.; Tanaka, N.; Jinadasa, K.B.S.N. \& Fasly, M.S.M. (2008). Effective coastal vegetative landscaping for the tsunami protection in Sri Lanka, Ann. Proc. of SLAAS.

Sasaki, Y.; Homchuen, S. \& Tanaka, N. (2007). The role of coastal vegetation in case of the Indian Ocean tsunami - Coastal area of Thailand and Sri Lanka -, Mangrove Science, Vol.4-5, 49-55.

Shuto, N. (1987). The effectiveness and limit of tsunami control forests, Coastal Engineering in Japan, Vol.30, No.1, 143-153.

Tanaka, N.; Sasaki, Y.; Mowjood, M.I.M.; Jinadasa, K.B.S.N. \& Takemura, T. (2006a). Effective coastal vegetation species and structures with landform, sand dune and lagoon, for tsunami protection at the Indian Ocean tsunami, Proceedings of 15 th APD-IAHR Congress, pp. 1279-1285, Chennai, India.

Tanaka, N.; Sasaki, Y. \& Mowjood, M.I.M. (2006b). Effects of sand dune and vegetation in the coastal area of Sri Lanka at the Indian Ocean tsunami, In: Eds, Namsik Park et al., Advances in Geosciences 6, World Scientific Publishing, Co.

Tanaka, N.; Sasaki, Y.; Mowjood, M.I.M. \& Jinadasa, K.B.S.N. (2007). Coastal vegetation structures and their functions in tsunami protection: Experience of the recent Indian Ocean tsunami, Landscape and Ecological Engineering, Vol.3, 33-45.

Tanaka, N. \& Sasaki, Y. (2007). Limitations of coastal vegetation in the 2004 Indian Ocean tsunami and 2006 Java tsunami, Proceedings of IAHR 32nd Congress, (CDROM), Venice, Italy.

Tanaka, N.; Karunarathna, A.K. \& Jinadasa, K.B.S.N. (2008a). Effect of coconut coir-pith supplement on nitrogen and phosphate removal in subsurface flow wetland microcosms, Chemistry and Ecology, Vol.24, No.1,1-8.

Tanaka, N.; Nandasena, N.A.K.; Jinadasa, K.B.S.N.; Tanimoto, K.; Sasaki, Y. \& Mowjood, M.I.M. (2009). Developing Effective vegetation bioshield for tsunami protection, Civil Engineering and Environmental Systems, Vol.26, No.2, 163 - 180.

Tanaka, N. (2009). Vegetation bioshields for tsunami mitigation: review of effectiveness, limitations, construction, and sustainable management, Landscape and Ecological Engineering, Vol. 5, No.1, 71-79.

Thuy, N.B.; Tanimoto, K.; Tanaka, N.; Harada K. \& Iimura, K. (2009). Effect of Open Gap in Coastal Forest on Tsunami Run-up - Investigations by Experiment and Numerical Simulation, Ocean Engineering, Vol. 36, 1258-1269. 
Thuy, N.B.; Tanaka, N. \& Tanimoto, K. (2010a). Damage length of vegetation due to tsunami action-Numerical model for tree breaking, Proceedings of 12th International Summer Sym. 101-104.

Thuy, N.B.; Tanimoto, K. \& Tanaka, N. (2010b). Force due to tsunami runup around a coastal forest with a gap - Experiments and numerical simulations, Science of Tsunami Hazards, Vol.29, No.2, 44-69. 


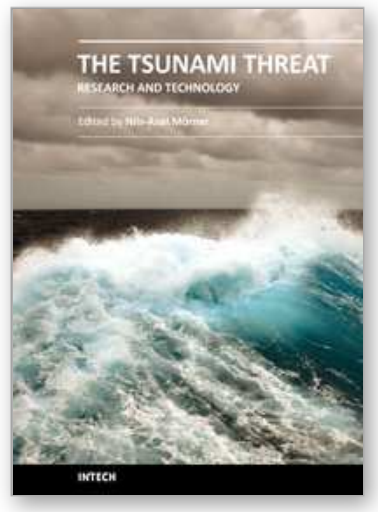

\author{
The Tsunami Threat - Research and Technology \\ Edited by Nils-Axel MÃ
}

ISBN 978-953-307-552-5

Hard cover, 714 pages

Publisher InTech

Published online 29, January, 2011

Published in print edition January, 2011

Submarine earthquakes, submarine slides and impacts may set large water volumes in motion characterized by very long wavelengths and a very high speed of lateral displacement, when reaching shallower water the wave breaks in over land - often with disastrous effects. This natural phenomenon is known as a tsunami event. By December 26, 2004, an event in the Indian Ocean, this word suddenly became known to the public. The effects were indeed disastrous and 227,898 people were killed. Tsunami events are a natural part of the Earth's geophysical system. There have been numerous events in the past and they will continue to be a threat to humanity; even more so today, when the coastal zone is occupied by so much more human activity and many more people. Therefore, tsunamis pose a very serious threat to humanity. The only way for us to face this threat is by increased knowledge so that we can meet future events by efficient warning systems and aid organizations. This book offers extensive and new information on tsunamis; their origin, history, effects, monitoring, hazards assessment and proposed handling with respect to precaution. Only through knowledge do we know how to behave in a wise manner. This book should be a well of tsunami knowledge for a long time, we hope.

\title{
How to reference
}

In order to correctly reference this scholarly work, feel free to copy and paste the following:

Norio Tanaka (2011). Effectiveness and Limitations of Vegetation Bioshield in Coast for Tsunami Disaster

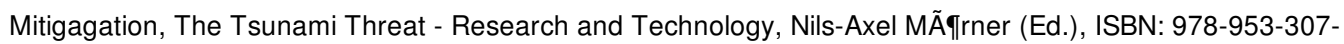
552-5, InTech, Available from: http://www.intechopen.com/books/the-tsunami-threat-research-andtechnology/effectiveness-and-limitations-of-vegetation-bioshield-in-coast-for-tsunami-disaster-mitigagation

\section{INTECH}

open science | open minds

\section{InTech Europe}

University Campus STeP Ri

Slavka Krautzeka 83/A

51000 Rijeka, Croatia

Phone: +385 (51) 770447

Fax: +385 (51) 686166

www.intechopen.com

\section{InTech China}

Unit 405, Office Block, Hotel Equatorial Shanghai

No.65, Yan An Road (West), Shanghai, 200040, China

中国上海市延安西路 65 号上海国际贵都大饭店办公楼 405 单元

Phone: +86-21-62489820

Fax: +86-21-62489821 
(C) 2011 The Author(s). Licensee IntechOpen. This chapter is distributed under the terms of the Creative Commons Attribution-NonCommercialShareAlike-3.0 License, which permits use, distribution and reproduction for non-commercial purposes, provided the original is properly cited and derivative works building on this content are distributed under the same license. 